\title{
PENGARUH ATRIBUT PRODUK TERHADAP KEPUASAN KONSUMEN MENGGUNAKAN SMARTPHONE MEREK ASUS DI KOTA PALU
}

\author{
PURNA SARI \\ H. CHALIL \\ ENGKI P. NAINGGOLAN \\ Program Studi S1 Manajemen Fakultas Ekonomi Universitas Tadulako \\ Email: phurna_shary@yahoo.co.id
}

\begin{abstract}
The purpose of this research is to know 1) the effect of product attribute variable consisting of product quality, features and design simultaneously to customer satisfaction using Asus brand smartphone in Palu City. 2) the effect of product quality variable on consumer satisfaction using Asus brand smartphone in Palu City. 3) the influence of feature variables on consumer satisfaction using Asus brand smartphone in Palu City. 4) the influence of design variables on consumer satisfaction using Asus brand smartphone in Palu City. This type of research is a survey research. The sample size is 60 respondents by using snowball sampling technique. The method of analysis is statistical analysis of Multiple Linear Regression. Result of research 1) variable of product attribute consisting of product quality, feature and design simultaneously have significant effect to consumer satisfaction using Asus brand smartphone in Palu City. 2) variable of product quality significantly influence to consumer satisfaction using Asus brand smartphone in Palu City. 3) feature variable significantly influence consumer satisfaction using Asus brand smartphone in Palu City. 4) design variables significantly influence consumer satisfaction using Asus brand smartphone in Palu City.
\end{abstract}

Keywords: Product Attributes, Product Quality, Features, Design, Consumer Satisfaction

Abstrak

Tujuan penelitian adalah untuk mengetahui 1) pengaruh variabel atribut produk yang terdiri dari kualitas produk, fitur dan desain secara serempak terhadap kepuasan konsumen menggunakan smartphone merek Asus di Kota Palu. 2) pengaruh variabel kualitas produk terhadap kepuasan konsumen menggunakan smartphone merekAsus di Kota Palu. 3) pengaruh variabel fitur terhadap kepuasan konsumen menggunakan smartphone merekAsus di Kota Palu. 4) pengaruh variabel desain terhadap kepuasan konsumen menggunakan smartphone merek Asus di Kota Palu.Tipe penelitian ini merupakan penelitian survey. Jumlahsampel 60 respondendenganmenggunakan teknik snowball sampling. Metode analisis adalah analisis statistik Regresi Linear Berganda (Multiple Linear Regression).Hasilpenelitian 1) variabel atribut produk yang terdiri dari kualitas produk, fitur dan desain secara serempak berpengaruhsignifikanterhadap kepuasan konsumen menggunakan smartphonemerekAsus di Kota Palu. 2) variabel kualitas produk berpengaruh signifikan terhadap kepuasan konsumen menggunakan smartphone merekAsus di Kota Palu. 3) variabel fitur berpengaruh signifikan terhadap kepuasan konsumen menggunakan smartphone merekAsus di Kota Palu. 4) variabel desain berpengaruh signifikan terhadap kepuasan konsumen menggunakan smartphone merek Asus di Kota Palu.

Kata Kunci: Atribut Produk, KualitasProduk, Fitur, Desain, Kepuasan Konsumen

\section{PENDAHULUAN}

Perkembangan smartphone sebagai media pada bidang teknologi dapat menunjang manusia untuk memperoleh informasi baik diaplikasikan dalam bentuk komunikasi (telephone \& pengiriman pesan melalui SMS), maupun dengan cara berkomunikasi melalui internet seperti Facebook, line, BBM, whatsaap, dan masih banyak lagi. Untuk itu, penjualan produk smartphone dengan berbagai macam merek tentunya memiliki atribut produk sebagai penarik konsumen dalam memilih dan memperoleh kepuasan terhadap penggunaan smartphone. 
Sari, P.

Berbagai macam merek smartphone yang telah beredar penjualannya di Sulawesi Tengah, khususnya di Kota Palu, di antaranya: Samsung, I-Phone, Oppo, Advan, dan lain-lain. Salah satunya adalah smartphone Asus Zenfone. Berdasarkan gambaran tentang smartphone Asus Zenfone yang diperoleh dari internet, yakni Asus Zenfone merupakan smartphone Android pertama Asus, meskipun ini adalah smartphone Android biasa, tapi Asus Zenfone tetap memiliki perbedaan dengan smartphone Android lain, yaitu memiliki prosesor intel. Selain itu, Asus Zenfone merupakan smartphone Android yang paling sukses di dunia dengan prosesor intel. Asus Zenfone juga mempunyai kamera yang bisa mengambil gambar dalam kondisi cahaya minim melalui low light mode, kemudian desain mewah dengan concentric circle dan performa yang smooth membuat smartphone ini sangat laku di pasaran.Zenfone tersedia dalam 3 buah model berdasarkan ukuran layar, mulai dari Zenfone 4, Zenfone 5 dan Zenfone 6. Saat ini Zenfone 4 sudah digantikan Zenfone 4C atau yang sering disebut dengan Zenfone 4S yang memiliki layar 4,5inchi. Sampai sekarang ketiga smartphone ini masih dijual meskipun Zenfone 2 sudah meluncur, karena Zenfone 2 merupakan Zenfone yang memiliki tipe lebih tinggi, bukan sebagai pengganti.

Skala global, Asus sejauh ini belum masuk dalam lima besar pemain yang menguasai pasar smartphone. Jika melihat data International Data Corporation (IDC)tahun 2016, dari total penjualan smartphone yang mencapai 362,19 juta unit, khusus pada kuartal III-2016, Samsung menempati peringkat pertama karena berhasil mengirimkan 72,5 juta unit, atau menguasai $20 \%$ pangsa pasar (market share) smartphone global. Pada urutan kedua, raksasa Apple, berhasil menjual iPone sebanyak 45,5 juta dengan pangsa pasar 12,5\%. Selanjutnya secara berurutan, ketiga hingga kelima, ditempati oleh vendor Tiongkok, yakni Huawei, Oppo, dan Vivo. Huawei menjual 33,6 juta dengan pangsa pasar 9,3\%, Oppo sebanyak 25,3 juta dengan market share 7\%, serta Vivo berhasil mengirimkan 21,2 juta dengan pangsa pasar 5,8\%. Sementara itu, sisanya, sebanyak 164,8 juta unit smartphone, atau setara 45,5\% market share global merupakan penjualan banyak merek dari berbagai belahan dunia. Hal itu termasuk data penjualan Asus.

Perkembangan Zenfone adalah suatu perkembangan teknologi yang mana sebelumnya Asus juga sudah memiliki banyak teknologi andalan miliknya yang digunakan pada laptop, notebook dan lain sebagainya. Teknologi ini juga yang kebanyakan digunakan pada perangkat tablet dan phablet maupun smartphone milik Asus, sehingga dalam persaingannya di pasar gadget tidak begitu sulit karena memang teknologi milik Asus sudah dibuktikan oleh banyak orang.

Penjualan smartphone Asus Zenfone tidak hanya mendominasi di Ibu Kota Provinsi, tapi juga sudah menyebar di level Kotadan bahkan di Kabupaten. Ini menunjukan bahwa populasi produk Smartphoneakan semakin besar. Fenomena yang di temukan di lapangan adalah sudah banyaknya pengguna smartphone Asus Zenfone di Kota Palu.Hal ini dibuktikan dengan banyaknya mahasiswa/mahasiswi bahkan masyarakat Kota Palu lainnya yang tidak sengaja di jumpai.Hal ini menunjukan bahwa Smartphone Asus Zenfone sudah mulai diminati oleh kalangan masyarakat di Kota Palu.Namun penjualan Smartphone Asus ini mulai menurun pada 2 tahun belakangan ini.

Secara umum, konsumen dalam melakukan pemilihan suatu produk, terlebih dahulu melihat atribut produk yang ditawarkan.Atribut produk adalah unsur-unsur produk yang dipandang penting oleh konsumen dan dijadikan dasar dalam pengambilan keputusan konsumen menggunakan produk. Menurut Tjiptono (2008:96) atribut produk adalah unsur-unsur produk yang dipersepsikan sangat penting oleh konsumen dan dijadikan dasar pengambilan keputusan pembelian suatu produk.

Kotler dan Amstrong (2008:272) menyatakan ada beberapa atribut produk yang menyertai dan melengkapi produk (karakteristik atribut produk) yaitu kualitas, fitur dan desain. Dalam penelitian ini atribut yang akan diteliti merupakan atribut-atribut yang terdapat pada produk Smartphone Asus yang terdiri dari kualitas, fitur dan desain.

Kualitas produk Smartphone Asusmemiliki daya tahan yang sangat kuat terhadap benturan ketika terjatuh ke lantai.Selain itu, layar Smartphone Asus sangat jernih ditambah dengan kerapatan layar dan 
dilengkapi dengan pelindung layar. Daya tahan baterainya juga mampu bertahan sampai 14 jam 36 menit karena Smartphone Asusmemiliki konsumsi listrik yang hemat walaupun kecepatan prosesornya sangat tinggi pada sistem operasinya. Dilihat dari segi fitur, Smartphone Asusdilengkapi dengan atribut tambahan seperti portable hotspot, kamera, dan dapat melakukan penambahan aplikasi apa saja yang diperlukan pengguna. Smartphone Asus juga memiliki sistem operasi android 4.3 jelly bean yang dapat melindungi keamanan handphone dari virus yang berbahaya, serta memiliki kecepatan dalam mentransfer data. Dilihat dari segi desain, Smartphone Asusmemiliki model terbaru setiap tahun dengan beraneka ragam warna dan ukuran layar yang elegan.

Tingkat kepuasan menunjukan pandangan konsumen akan produk yang akan dibeli dan digunakannya lagi, dengan pelanggan puas akan produk dengan merek yang sama maka besar kemungkinan konsumen mmelakukan pembelian ulang dengan merek yang sama. Pengguna Smartphone Asus melakukan suatu keputusan didalam membeli sebuah produk dipengaruhi oleh berbagai faktor.Faktor-faktor yang dipertimbangkan terdiri dari kualitas produk, fitur produk dan desain produk yang ditunjukan lewat atribut sebuah produk. Adanya atribut produk yang diberikan terhadap produk maka akan mampu menarik konsumen untuk melakukan keputusan pembelian dan diharapkan konsumen akan puas menggunakan produk tersebut.

Berdasarkan gambaran smartphone Asus Zenfone yang telah diuraikan di atas, maka tujuan penelitian adalah untuk mengetahui pengaruh secarabersama-samadanparsialvariabel atribut produk yang terdiri dari kualitas produk, fitur dan desain terhadap kepuasan konsumen menggunakan smartphone merek Asus di Kota Palu.

\section{KAJIAN LITERATUR DAN PENGEMBANGAN HIPOTESIS Atribut Produk.}

Kotler dan Amstrong (2008:272) menyatakan ada beberapa atribut produk yang menyertai dan melengkapi produk (karakteristik atribut produk) yaitu kualitas, fitur dan desain. Atribut yang akan diteliti merupakan atribut-atribut yang terdapat pada produk Smartphone Asus yang terdiri darii kualiitas, fitur dan desain

Tjiptono (2008:103) atribut produk adalah pengembangan suatu peroduk atau jasa untuk menentukan manfaat yang akan diberikan kepada konsumen, yang terdiri atas kualitas, merek, kemasan, lebel dan jasa pendukung. Perbedaan atribut produk yang ditawarkan oeh perusahaan secara langsung memberikan dampak terhadap tanggapan konsumen atas suatu produk.Hal ini membuktikan bahwa atribut produk merupakan faktor penting yang dipertimbangkan oleh kosumen karena merupakan jaminan atas keunggulan produk yang ditawarkan.

\section{Kualitas Produk}

Kualitas produk adalah kemampuan suatu produk untuk melakukan fungsi-fungsinya ditunjukan melalui kualitas produk itu sendiri, dimana yang menjadi tolak ukur kemampuan atas produk adalah daya tahan, kehandalan, kemudahan pengoperasian, kemudahan untuk diperbaiki dan atribut lain yang berharga. Oleh karna itu kualitas berhubungan erat dengan nilai dan kepuasan pelanggan.

Sunarto (2003:222) kualitas produk adalah salah satu alat utama untuk positioning (menetapkan posisi) bagi pemasar.Kualitas produk mempunyai dua dimensi atau tingkat dan konsistensi.Melaluipengembangan suatu produk, pemasar awalnya harus memilih tingkat kualitas yang akan mendukung posisi produk di pasar sasaran.

Irawan (2002:45) mengatakan bahwa kualitas produk (product quality) merupakan driver kepuasan pelanggan yang multidimensi.Bagi konsumen, kualitas mempunyai beberapa dimensi.Paling tidak, terdapat beberapa dimensi dari kualitas produk. Dimensi kualitas produk tersebut terdri dari:

1. Performance (kinerja). Ini adalah dimensi yang paling mendasar dan berhubungan dengan fungsi utama suatu produk. 
Sari, P.

2. Reliability (kehandalan). Lebih menunjukan probabilitas produk gagal menjalankan fungsinya.

3. Durability (daya tahan) menunjukan suatu pengukuran terhadap siklus produk, baik secara teknis maupun waktu.

4. Conformance (kesesuaian). Dimensi ini menunjukan seberapa jauh suatu produk dapat menyamai standar atau spesifikasi tertentu.

5. Design. Dimensi ini banyak menawarkan aspek emosional dalam suatu produk.

\section{Fitur}

Upaya untuk menciptakan tingkatan yang lebih tinggi atas suatu produk maka perusahaan perlu meningkatkan inovasi untuk manciptakan dan menawarkan fitur-fitur produk yang lebih menarik dibandingkan dengan produk yang suda ada dipasar. Selain itu, dapat juga mendiferensiasi produk yang dihasilkan oleh perusahaan terhadap produk sejenis yang dihasilkan perusahaan lain.

Kotler dan Amstrong (2008:273) fitur adalah saran kompetitif untuk mendiferensiasikan produk perusahaan dari produk pesaing.Fitur sebuah produk dapat ditawarkan dalam beragam fitur.Model dasar, model tanpa tambahan apapun, merupakan titik awal.Perusahaan dapat menciptakan tingkat model yang lebih tinggi dengan menambahkan lebih banyak fitur. Menjadi produsen pertama yang memperkenalkan fitur baru yang bernilai adalah salah satu cara paling efektif untuk bersaing.

\section{Desain}

Desain sangat penting terutama dalam pembuatan dan pemasaran jasa eceran, busana, barang kemasan, dan peralatan tahan lama. Desainer harus menemukan berapa banyak yang diinvestasikan dalam bentuk, pengembangan fitur, kinerja, kesesuaian, ketahanan, keandalan, kemudahan perbaikan dan gaya.

Kotler dan Keller (2009:10) desain adalah totalitas fitur yang mempengaruhi tampilan, rasa, dan fungsi produk berdasarkan kebutuhan pelanggan.Sedangkan Gobe (2005:7) menyatakan bahwa desain produk yang baik harus memberikan pengalaman sentuhan yang menyenangkan bagi pelanggan. Gobe meyakini bahwa dalam membeli sesuatu konsumen tidak hanya memerlukan informasi mengenai produk, mereka cenderung menyentuh produk untuk proses evaluasi.

\section{Kepuasan Konsumen}

Tjiptono (2008:24)menyatakanbahwa kepuasan pelanggan adalah respon pelanggan terhadap evaluasi ketidaksesuaian yang dirasakan antara harapan sebelumnya (norma kinerja lainnya) dan kinerja aktual produk yangdirasakan setelah pemakaiannya. Selain itu, pelanggan juga memiliki pengertian sebagai orang yang menerima hasil pekerjaan seseorang atau suatu organisasi, sehingga merakalah yang dapat menentukan kualitas seperti apa dan bagaimana kebutuhan mereka Jika produk yang diinginkan konsumen sesua dengan apa yang diinginkannyamaka konsumen akan merasa puas.

Tjiptono (2006:146)menyatakan bahwa kepuasan pelanggan merupakan evaluasi purna beli dimana alternatif yang dipilih sekurang-kurangnya sama atau melampaui harapan pelanggan, sedangkan ketidakpuasan timbul apabila hasil tidak memenuhi harapan. Sedangkan Rangkuti (2004:23) kepuasan pelanggan adalah perasaan senang atau kecewa seseorang sebagai hasil dariperbandingan antara produk yang dirasakan dan yang diharapkan.

\section{Hubungan Atribut Produk dengan Kepuasan Konsumen}

Setiap perusahaan berusaha untuk memuaskan kebutuhan dan keinginan konsumen melalui produk yang ditawarkan, sedangkan konsumen mencari manfaat tertentu yang ada pada suatu produk. Konsumen mlihat setiap produk sebagai kumpulan dari sifat-sifat ciri tertentu yang tercermin dari atribut-atribut yang melekat pada suatu produk atribut yang berupa kualiitas produk, desain produk, dan fitur produk. Kebanyakan konsumen melihat atribut sebagai keseluruhan isi dari produk yang akan mereka beli.

Atribut adalah unsur-unsur atribut yang dipandang penting oleh konsumen dan dijadikan dasar untuk memuaskan setiap keinginannya pada produk tersebut. Konsumen memandang atribut sebagai bagian penting dari suatu produk, karena itu perusahaan berusaha merancang, menciptakan kemudian 
merealisasikan sebuah atribut produk yang terdapat pada produk tersebut. Seorang konsumen sebelum mengkonsumsi sebuah produk dimulai dengan pengenalan masalah untuk mengetahui apa yang mereka inginkan. Atribut produk dapat dikatakan mempunyai pengaruh bagi konsumen dalam memuaskan kebutuhan maupun keinginannya, sehinggaatribut produk mempunyai hubungan dengan kepuasan konsumen.

\section{Hubungan Antara Kualitas Produk Terhadap Kepuasan Konsumen}

Kotler (2008:272) bahwa kualitas produk merupakan karakteristik produk atau jasa yang tergantung pada kemampuannya untuk memuaskan kebutuhan pelanggan yang dinyatakan atau diimplikasikan. Jadi kualitas produk merupakan hal yang sangat perlu diperhatikan perusahaan, karena dengan kualitas yang baik akan memberikan kepuasan, kepercayaan kepada konsumen dalam penggunaannya yang kemudian menjadi motivasi konsumen untuk membeli ulang produk tersebut. Produk dikatakan mempunyai kinerja yang baik apabila produk tersebut mampu bekerja sesuai dengan keinginan konsumen dan mempunyai reliabilitas yang baik apabila memiliki kegunaan selama pemakaian. Disamping memenuhi keinginan konsumen juga meningkatkan penjualan perusahaan yang pada akhirnya meningkatkan laba perusahaan. Sebaliknya jika kualitas produk yang dihasilkan oleh perusahaan kurang baik maka akan menurunkan penjualan dan laba perusahaan juga akan menurun pula.

Kualitas produk yang diberikan oleh suatu perusahaan sangat erat dengan kepuasan yang dirasakan oleh konsumen. Apabila perusahaan memberikan kualitas produk yang baik dan sesuai dengan harapan konsumen maka konsumen akan merasa puas, namun sebaliknya apabila kualitas produk yang diberikan tidak sesuai dengan harapan konsumen maka konsumen akan merasa tidak puas. Pemenuhan harapan konsumen sangat perlu diperhatikan hal ini untuk menarik hati konsumen agar menjadi konsumen yang setia.Kepuasan pelanggan dianggap sebagai gagasan yang sangat penting dan menjadi tujuan utama dalam pemasaran.Berdasarkan pengertian di atas, maka dapat disimpulkan bahwa kualitas produk mempengaruhi kepuasan pembelian suatu produk.Apabila kualitas produk semakin tinggi maka kepuasan pelanggan juga semakin meningkat. Kualitas produk merupakan salah satu sarana positioning utama dalam memasuki pasar.Kualitas mempunyai dampak langsung pada kinerja produk atau jasa; oleh sebab itu, kualitas memiliki hubungan erat dengan nilai dan kepuasan pelanggan (Kotler, 2008:272).

\section{Hubungan Antara Fitur Terhadap Kepuasan Konsumen}

Fitur merupakan karakteristik yang melengkapi fungsi dasar suatu produk.Perusahaan dapat menciptakan model tingkatan yang lebih tinggi dengan menambahkan berbagai fitur. Beberapa produsen yang inovatif selalu berusaha menciptakan fitur-fitur produk yang lebih menarik dibandingkan dengan produk pesaing mereka, dan itu merupakan salah satu cara yang efektif untuk memenangkan persaingan. Fitur dapat dikatakan sebagai aspek sekunder.Karena perkembangan fitur ini hampir tidak ada batasnya sejalan dengan perkembangan teknologi, maka fitur menjadi target para produsen utnuk berinovasi dalam upaya memuaskan pelanggan.Hal yang perlu dicatat dalam dimensi fitur ini adalah kenyataan bahwa kepuasan pelanggan terhadap fitur selalu dimediasi dengan harga.Hampir selalu terjadi bahwa penambahan fitur selalu mengakibatkan kenaikan harga dari produk tersebut.Salah satu hal yang dipertimbangkan konsumen untuk berpindah merek adalah rancang desain yang menjadi bagian yang penting di samping fitur teknologinya sendiri.Jika konsumen merasa puas terhadap desainnya maka muncul keinginan untuk untuk menggunakan produk tersebut.

Tjiptono (2008:93) kepuasan pelanggan terhadap suatu produk atau jasa sangat dipengaruhi oleh hasil evaluasi pelanggan pada fitur produk atau jasa.Pelanggan dapat menyatakan puas atau tidak puas setelah menggunakan produk tersebut.Kepuasan pelanggan terhadap produk atau jasa secara signifikan dipengaruhi oleh evaluasi pelanggan terhadap fitur produk atau jasa. 


\section{Hubungan Antara Desain Terhadap Kepuasan Konsumen}

Kotler dan Keller (2009:10) ketika persaingan semakin kuat, desain menawarkan satu cara potensial untuk mendiferensiasikan serta memposisikan produk dan jasa perusahaan. Desain merupakan faktor yang sering memberi keunggulan kompetitif kepada perusahaan.Desain (design) adalah totalitas fitur yang mempengaruhi tampilan, rasa, dan fungsi produk berdasarkan kebutuhan pelanggan. Desain produk yang disesuaikan dengan keinginan dan harapan konsumen akan memberikan kepuasan tersendiri bagi penggunanya.

Desain produk yang baik juga berhubungan erat dengan tingkat kepuasan konsumen.Masalah desain dari suatu produk telah menjadi salah satu faktor yang perlu mendapatkan perhatian serius dari manajemen khususnya team pengembangan produk baru, karena sasaran konsumen yang dituju tidak sedikit yang mulai mempersoalkan masalah desain suatu produk yang mampu memenuhi kebutuhan dan keinginan konsumen.Berdasarkan pengertian di atas, maka desain berpengaruh positif dan signifikan terhadap kepuasan konsumen (Kotler dan Keller, 2009:10).

\section{Hipotesis}

1. Atribut produk yang terdiri dari Kualitas produk, Fitur dan Desain berpengaruh signifikan terhadap kepuasan konsumen smartphone merek Asus di Kota Palu.

2. Kualitas produk berpengaruh signifikan terhadap kepuasan konsumen smartphone merek Asus di Kota Palu.

3. Fitur berpengaruh signifikan terhadap kepuasan konsumen smartphone merek Asus di Kota Palu.

4. Desain berpengaruh signifikan terhadap kepuasan konsumen smartphone merek Asus di Kota Palu.

\section{METODE PENELITIAN Jenis Penelitian}

Tipe penelitian ini merupakan penelitian deskriptif kausal.Penelitian deskriptif kausal menurut Umar (2008:87) adalah penelitian yang bertujuan untuk menggambarkan sifat sesuatu yang tengah berlangsung pada saat riset dilakukan dan memeriksa sebab-sebab dari suatu gejala tertentu.Sedangkan kausalitas adalah penelitian yang bertujuan untuk mengetahui hubungan antara dua variabel atau lebih, atau bagaimana satu variabel mempengaruhi variabel lain

\section{Objek dan Subjek Penelitian}

Kurniawan (2014:69) objek penelitian adalah sifat keadaan (attributes) dari satu benda, orang, atau keadaan, yang menjadi pusat perhatian sasaran penelitian. Subjek penelitian adalah sesuatu baik orang, benda atau lembaga (organisasi), yang sifat keadaannya (atributnya) akan diteliti. Maka dalam penelitian ini yang menjadi objek penelitian adalah atribut produk dan kepuasan konsumen, sedangkan subjek penelitian adalah semua konsumen yang menggunakan smartphone merek Asus di Kota Palu.

\section{Metode Pengumpulan Data}

1. Wawancara Langsung, merupakan metode yang digunakan untuk memperoleh informasi secara langsung, mendalam, tidak terstruktur, dan individual. Melalui wawancara, seorang respoden diajukan pertanyaan oleh pewawancara untuk mengungkapkan perasaan, motivasi, sikap, atau keyakinan terhadap suatu topik dimana penulis mengadakan tanya jawab kepada semua pihak yang terkait dengan penelitian ini.

2. Observasi Langsungadalah proses mengenali dan mencatat kejadian serta objek yang relevan secara langsung. Observasi atau melakukan pengamatan terhadap perilaku subjek yang sedang diteliti kemudian dilakukan pencatatan langsung tentang apa yang sedang diamati.

3. Kuesioner (Angket), yakni peneliti mengedarkan sejumlah daftar pertanyaan terstruktu yang sifatnya tertutup kepada para konsumen yang menggunakan smartphone merek Asus di Kota Palu yang dijadikan responden dalam penelitian ini. 


\section{Populasi dan Sampel}

Populasi adalah masyarakat yang menggunakan smartphone merek Asus di Kota Palu.Jumlah penduduk Kota Palu tahun 2017 sebanyak 374.020 jiwa.Berdasarkanumlah tersebut, jumlah masyarakat yang menggunakan smartphone Asus di Kota Palu tidak diketahui secara pasti jumlah secara keseluruhan sehingga digunakan teknik snowball sampling, yaitu teknik penentuan sampel yang mula-mula jumlahnya kecil, kemudian membesar. Penentuan sampel, pertama-tama dipilih satu atau dua orang, kemudian dua orang ini disuruh memilih teman-temannya untuk dijadikan sampel. Begitu seterusnya sehingga jumlah sampel semakin banyak (Sugiyono, 2014:86). Jumlah sampel yang akan digunakan dalam penelitian ini berdasarkan teknik snowball sampling adalah sebanyak 60 responden pengguna smartphone merek Asus di Kota Palu.

\section{Metode Analisis}

Analisis regresi pada dasarnya adalah studi mengenai ketergantungan variabel dependen dengan variabel independen dengan tujuan untuk mengestimasi atau memprediksi rata-rata populasi atau nilai rata-rata variabel dependen berdasarkan nilai variabel independen yang diketahui.Model umum bentuk persamaan alat analisis statistik parametrik Regresi Linear Berganda (Multiple Regression Linear) menurut Sugiyono (2014:277):

$$
\mathrm{Y}=\mathrm{a}+\quad+\quad+\quad+\ldots \ldots .+
$$

\section{Pengujian Hipotesis Pertama (Uji F)}

1. Jika Probabilitas ( $\operatorname{sig}$ F) $\leq \alpha=0,05$, atau tingkat kepercayaan $95 \%$, maka terbukti bahwa semua variabel independen $(\mathrm{X})$ secara serempak berpengaruh signifikan terhadap variabel dependen (Y) dengan kata lain hipotesis yang diajukan dapat diterima kebenarannya.

2. Jika Probabilitas ( $\operatorname{sig} F$ ) $>\alpha=0,05$, atau tingkat kepercayaan $95 \%$, maka terbukti bahwa semua variabel independen $(\mathrm{X})$ secara serempak berpengaruh tidak signifikan terhadap variabel dependen (Y) dengan kata lain hipotesis yang diajukan tidak dapat diterima kebenarannya.

\section{Pengujian Hipotesis Kedua (Uji t)}

a. Jika Probabilitas (sig $t) \leq \alpha=0,05$, atau tingkat kepercayaan 95\%, maka terbukti bahwa semua variabel independen $(\mathrm{X})$ secara parsial berpengaruh signifikan terhadap variabel dependen (Y) dengan kata lain hipotesis yang diajukan dapat diterima kebenarannya.

b. Jika Probabilitas (sig t) $>\alpha=0,05$, atau tingkat kepercayaan $95 \%$, maka terbukti bahwa semua variabel independen $(\mathrm{X})$ secara parsial berpengaruh tidak signifikan terhadap variabel dependen (Y) dengan kata lain hipotesis yang diajukan tidak dapat diterima kebenarannya.

\section{HASIL DAN PEMBAHASAN}

\section{Hasil Penelitian}

\section{Deskripsi Variabel Kualitas Produk}

Pernyataan variabel kualitas produkdigolongkan pada kriteria sangat baik dengan skor rata-rata (Mean) jawaban responden yang tertinggi adalah indikator pernyataan kedua (Smartphone Asus memiliki layar yang jernih) sebesar 4,42 dan yang terendah adalah indikator pernyataan ketiga (Smartphone Asus memiliki daya tahan baterai yang tahan lama) sebesar 4,08. Dilihat dari hasil skor rata-rata jawaban responden sebesar 4,22 maka, dapat disimpulkan bahwa kualitas produk smartphone merek Asus dinilai oleh pengguna di Kota Palu sangat baik.

\section{Deskrisi Variabel Fitur}

Pernyataan variabel fitur digolongkan pada kriteria sangat baik dengan skor rata-rata (Mean) jawaban responden yang tertinggi adalah indikator pernyataan ketiga (Smartphone Asus memiliki sistem operasi yang aman) sebesar 4,45 dan yang terendah adalah indikator pernyataan pertama (Ketersediaan aplikasi smartphone Asus sangat terbatas) sebesar 4,28. Dilihat dari hasil skor rata-rata 
Sari, P.

jawaban responden sebesar 4,34 maka, dapat disimpulkan bahwa fitur smartphone merek Asus dinilai oleh pengguna di Kota Palu sangat baik.

\section{Deskripsi Variabel Desain}

Pernyataan variabel desaindigolongkan pada kriteria sangat baik dengan skor rata-rata (Mean) jawaban responden yang tertinggi adalah indikator pernyataan kelima (Smartphone Asus memiliki beberapa ukuran layar yang beragam) sebesar 4,28 dan yang terendah adalah indikator pernyataan keempat (Smartphone Asus memiliki beberapa tampilan yang beragam) sebesar 4,12. Dilihat dari hasil skor rata-rata jawaban responden sebesar 4,28 maka, dapat disimpulkan bahwa desain smartphone merek Asus dinilai oleh pengguna di Kota Palu sangat baik.

\section{Deskripsi Variabel Kepuasan Konsumen}

Pernyataan variabel kepuasan konsumendigolongkan pada kriteria baik dengan skor rata-rata (Mean) jawaban responden yang tertinggi adalah indikator pernyataan kedua (Merekomendasikan smartphone Asus kepada orang lain) sebesar 4,25 dan yang terendah adalah indikator pernyataan ketiga (Memberikan komentar yang positif tentang perusahaan) sebesar 4,00. Dilihat dari hasil skor rata-rata jawaban responden sebesar 4,12 maka, dapat disimpulkan bahwa kepuasan konsumen smartphone merek Asus dinilai oleh pengguna di Kota Palu baik.

\section{Hasil Pengujian Regresi Linier Berganda}

Pengujian regresi linier berganda merupakan suatu analisa kuantitatif yang digunakan untuk menghitung koefisien regresi.Adapun variabel-variabel yang digunakan dalam perhitungan ini terdiri dari kualitas produk $\left(\mathrm{X}_{1}\right)$, fitur $\left(\mathrm{X}_{2}\right)$ dan desain $\left(\mathrm{X}_{3}\right)$ yang merupakan variabel independen dan kepuasan konsumen (Y) sebagai variabel dependen. Hasil pengujian diperoleh persamaan regresi berganda, yaitu sebagai berikut:

$\mathrm{Y}=-3,182+0,602 \mathrm{X}_{1}+0,811 \mathrm{X}_{2}+0,248 \mathrm{X}_{3}(2)$

a. Nilai konstanta sebesar -3,182 memiliki arti bahwa kepuasan konsumen sebesar -3,182 tanpa variabel kualitas produk $\left(\mathrm{X}_{1}\right)$, fitur $\left(\mathrm{X}_{2}\right)$, desain $\left(\mathrm{X}_{3}\right)$ diteliti.

b. Nilai koefisien variabel kualitas produk $\left(\mathrm{X}_{1}\right)$ sebesar 0,602 memiliki arti bahwa terdapat hubungan positif antara variabel kualitas produkdengan kepuasan konsumen, atau dengan kata lain apabila variabel kualitas produk meningkat, maka kepuasan konsumen juga akan meningkat. Karena nilai koefisien regresi bernilai positif atau searah.

c. Nilai koefisien variabel fitur $\left(\mathrm{X}_{2}\right)$ sebesar 0,811 memiliki arti bahwa terdapat hubungan positif antara variabel fiturdengan kepuasan konsumen, atau dengan kata lain apabila variabel fitur meningkat, maka kepuasan konsumen juga akan meningkat. Karena nilai koefisien regresi bernilai positif atau searah.

d. Nilai koefisien variabel desain $\left(\mathrm{X}_{3}\right)$ sebesar 0,248 memiliki arti bahwa terdapat hubungan positif antara variabel desaindengan kepuasan konsumen, atau dengan kata lain apabila variabel desain meningkat, maka kepuasan konsumen juga akan meningkat. Karena nilai koefisien regresi bernilai positif atau searah.

Besarnya keterkaitan antara variabel atribut produk (kualitas produk, fitur, dan desain) terhadap kepuasan konsumen menggunakan smartphone merek Asus di Kota Palu dapat dilihat pada nilai $\mathrm{R}$ yaitu sebesar 0,725 . Nilai tersebut dapat dikatakan bahwa terjadi hubungan erat antara ketiga variabel independen terhadap variabel dependen dengan nilai hubungan sebesar $72,5 \%$, sehingga ketiga variabel dependen tersebut layak untuk diteliti.

\section{Hasil Pengujian Hipotesis Secara Serempak}

Uji F digunakan untuk menguji pengaruh variabel independen terhadap variabel dependen secara serempak. Hasil perhitungan statistik menunjukkan nilai sig. $F=0,000$. Bila nilai sig. $F$ tersebut dibandingkan dengan $\alpha=0,05$, maka nilai prob (sig. F) $=0,000<\alpha=0,05$ atau tingkat kepercayaan $95 \%$, maka terbukti bahwa semua variabel independen (kualitas produk, fitur, dan desain) secara 
serempak berpengaruh signifikan terhadap variabel dependen (kepuasan konsumen pengguna smartphonemerek Asus di Kota Palu) dengan kata lain hipotesis pertama yang diajukan dapat diterima kebenarannya.

Adapun besarnya pengaruh semua variabel independen terhadap variabel dependen ditunjukan pada nilai $R$ Square sebesar 0,526 atau sebesar 52,6\% dan sisanya 47,4\% dipengaruhi oleh variabel lain yang tidak dimasukan dalam penelitian ini, sepertivariabelharga, nilaimanfaat, ekuitasmerekdan lain-lain.

\section{Hasil Pengujian Hipotesis Secara Parsial}

1) Variabel Kualitas Produk $\left(X_{1}\right)$

Variabel kualitas produk memiliki nilai sig. $\mathrm{t}=0,000<\alpha=0,05$ atau tingkat kepercayaan $95 \%$, maka terbukti bahwa variabel kualitas produk secara parsial berpengaruh signifikan terhadap variabel kepuasan konsumen pengguna smartphonemerek Asus di Kota Palu, dengan kata lain hipotesis kedua yang diajukan dapat diterima kebenarannya.

2) Variabel Fitur $\left(X_{2}\right)$

Variabel fitur $\left(\mathrm{X}_{2}\right)$ memiliki nilai sig. $\mathrm{t}=0,000<\alpha=0,05$ atau tingkat kepercayaan $95 \%$, maka terbukti bahwa variabel fitur secara parsial berpengaruh signifikan terhadap variabel kepuasan konsumen pengguna smartphonemerek Asus di Kota Palu, dengan kata lain hipotesis ketiga yang diajukan dapat diterima kebenarannya.

3) Variabel Desain $\left(X_{3}\right)$

Variabel desain $\left(X_{3}\right)$ memiliki nilai sig. $t=0,024<\alpha=0,05$ atau tingkat kepercayaan $95 \%$, maka terbukti bahwa variabel desain secara parsial berpengaruh signifikan terhadap variabel kepuasan konsumen pengguna smartphonemerek Asus di Kota Palu, dengan kata lain hipotesis keempat yang diajukan dapat diterima kebenarannya.

\section{Pembahasan}

\section{Pengaruh Variabel Kualitas Produk Terhadap Kepuasan Konsumen}

Hasil penelitian menunjukkan bahwa variabel kualitas produk berpengaruh signifikan terhadap kepuasan konsumen menggunakan smartphone merek Asus.Sesuai hasil penelitian di lapangan terhadap kepuasan konsumen menggunakan smartphone merek Asus dari 5 (lima) item indikator dari variabel ini adalah daya tahan, layar, baterai, prosesor, dan hemat listrik, semuanya memberikan pengaruh signifikan terhadap kepuasan konsumen menggunakan smartphone merek Asus di Kota Palu. Jadi artinya, bahwa variabel kualitas produk memiliki pengaruh signifikan terhadap kepuasan konsumen menggunakan smartphone merek Asus di Kota Palu. Hasil pendapat yang mengatakan mendukung dari penelitian Saputra, Hidayat, dan Sunarti (2017), bahwa kualitas produk berpengaruh signifikan terhadap kepuasan konsumen pengguna Iphone.

Berdasarkan tanggapan responden terhadap variabel kualitas produk, resonden menilai kualitas produk smartphone merek Asus sangat baik.Dilihat dari segi daya tahan telah terbukti bahwa smartphone Asus memiliki desain premium dengan material berkualitas tinggi sehingga tahan ketika terbentur/terjatuh ke lantai. Selain itu, smartphone Asus juga menggunakan bahan plastik sebagai pembalut bodinya, kelebihan berbalut plastik adalah: cukup lentur sehingga tidak mudah bengkok. Umumnya memilih back cover yang bisa dibongkar pasang atau diganti-ganti. Dilihat dari segi layar, telah terbukti bahwa Smarthone Asus memiliki kualitas layarnya yang menawan dan mampu menghasilkan kualitas layar yang jernih dan sudut pandang yang luas, ditambah dengan kerapatan layar untuk ketajamannya, tidak lupa juga dengan pelindung layar.

Dilihat dari segi baterai, terbukti bahwa smartphone Asus memiliki daya tahan baterai yang terbilang baik mencapai 14 jam 36 menit. Dilihat dari prosesor, terbukti bahwa smartphone Asus memiliki kecepatan prosesor yang dilengkai dengan intel sehingga sistem operasi sangat cepat seperti mengedit gambar atau video, membuat sketsa atau gambar, mengolah dokumen melalui media online, 
Sari, P.

bermain game berat, streaming video dan lain-lainnya. Dilihat dari segi tegangan listrik, terbukti bahwa smarthone Asus memiliki konsumsi listrik yang hemat. Ketika melakukan pengisian ulang daya baterai, dari keadaan kosong, membutuhkan waktu sekitar 1 menit 30 detik untuk mencapai titik 2\%, di mana smartphone sudah bisa dihidupkan. Kemudian, pengisian ulang daya dari $2 \%$ ke $100 \%$ membutuhkan waktu sekitar 1 jam 54 menit. Secara keseluruhan, dari kondisi kosong hingga penuh, isi ulang baterai dari smartphone Asus ini membutuhkan waktu 1 jam 55 menit dengan adapter dari paket penjualannya. Hal ini menunjukkan bahwa smartphone Asus menawarkan pengisian ulang baterai yang cukup cepat, tidak bisa dikatakan sangat cepat, tetapi sudah lebih cepat dibandingkan dengan pengisian ulang baterai $3000 \mathrm{mAh}$ tanpa kapabilitas fast charging.

Hasil penelitian menunjukkan bahwa variabel kualitas produk berpengaruh signifikan terhadap kepuasan konsumen.Menurut Kotler (2008:272) bahwa.kualitas produk yang diberikan oleh suatu perusahaan sangat erat dengan kepuasan yang dirasakan oleh konsumen. Apabila perusahaan memberikan kualitas produk yang baik dan sesuai dengan harapan konsumen maka konsumen akan merasa puas, namun sebaliknya apabila kualitas produk yang diberikan tidak sesuai dengan harapan konsumen maka konsumen akan merasa tidak puas. Apabila kualitas produk semakin tinggi, maka kepuasan pelanggan juga semakin meningkat.

\section{Pengaruh Variabel Fitur Terhadap Kepuasan Konsumen}

Hasil penelitian menunjukkan bahwa variabel fitur berpengaruh signifikan terhadap kepuasan konsumen menggunakan smartphone merek Asus.Sesuai hasil penelitian dilapangan terhadap kepuasan konsumen menggunakan smartphone merek Asus dari 5 (lima) item indikator dari variabel ini adalah aplikasi, portabel hotspot, sistem informasi, dan transfer data, semuanya memberikan pengaruh signifikan terhadap kepuasan konsumen menggunakan smartphone merek Asus di Kota Palu. Jadi artinya, bahwa variabel fitur memiliki pengaruh signifikan terhadap kepuasan konsumen menggunakan smartphone merek Asus di Kota Palu. Hasil pendapat yang mengatakan mendukung dari penelitian Saputra, Hidayat, dan Utama dan Amelia (2009), bahwa fitur yang termasuk dalam atribut produk berpengaruh signifikan terhadap kepuasan pelanggan.

Berdasarkan tanggapan responden terhadap variabel fitur, resonden menilai fitur smartphone merek Asus sangat baik.Dilihat dari segi aplikasi telah terbukti bahwa smartphone Asus memiliki keterbatasan aplikasi bawaan ketika pertamakali membeli, dan untuk menambah aplikasi cuku dengan mendownload aplikasi yang diperlukan tanpa adanya keterbatasan aplikasi. Dilihat dari segi portabel hotspot, terbukti bahwa smartphone Asus dapat digunakan sebagai portabel hotspot yang dapat menghubungkan wi-fi dengan komputer atau handphone merek apa saja atau melalui USB tethering. Dilihat dari segi sistem informasi, smarthone Asus memiliki sistem operasi android 4.3 jelly bean yang tertanam didalamnya yang dapat melindungi keamanan handphone dari pengunduhan aplikasi yang tidak aman atau mengandung virus. Dilihat dari segi transfer data, terbukti bahwa smarthone Asus memiliki tingkat kecepatan dalam mentransfer data, baik berupa file, foto, video, game, dan lain sebagainya dengan menggunakan berbagai aplikasi transfer seperti BBM, line, whatsaap, facebook, massanger, instagram, dan lain-lainnya.

Hasil penelitian menunjukkan bahwa variabel fitur berpengaruh signifikan terhadap kepuasan konsumen.Menurut Tjiptono (2008:93) bahwa salah satu hal yang dipertimbangkan konsumen untuk berpindah merek adalah fitur.Jika konsumen merasa puas terhadap desainnya maka muncul keinginan untuk untuk menggunakan produk tersebut.Kepuasan pelanggan terhadap suatu produk atau jasa sangat dipengaruhi oleh hasil evaluasi pelanggan pada fitur produk atau jasa.Pelanggan dapat menyatakan puas atau tidak puas setelah menggunakan produk tersebut.Kepuasan pelanggan terhadap produk atau jasa secara signifikan dipengaruhi oleh evaluasi pelanggan terhadap fitur produk atau jasa.

\section{Pengaruh Variabel Desain Terhadap Kepuasan Konsumen}


Hasil penelitian menunjukkan bahwa variabel desain berpengaruh signifikan terhadap kepuasan konsumen menggunakan smartphone merek Asus.Sesuai hasil penelitian dilapangan terhadap kepuasan konsumen menggunakan smartphone merek Asus dari 5 item indikator dari variabel ini adalah model, bentuk, warna, desain, dan ukuran layar, semuanya memberikan pengaruh signifikan terhadap kepuasan konsumen. Jadi artinya, bahwa variabel desain memiliki pengaruh signifikan terhadap kepuasan konsumen menggunakan smartphone merek Asus di Kota Palu. Hasil pendapat yang mengatakan mendukung dari penelitian Utama dan Amelia (2009), bahwa desain yang termasuk dalam atribut produk berpengaruh signifikan terhadap kepuasan pelanggan.

Berdasarkan tanggapan responden terhadap variabel desain, resonden menilai desain smartphone merek Asus sangat baik. Dilihat dari segi model telah terbukti bahwa smartphone Asus memiliki model yang terbaru setiap tahun dan sudah mempunyai fan branded di Indonesia cukup tinggi. Asus sudah mempunyai nama yang cukup besar serta ditunjang oleh kualitas produk tidak diragukan lagi, maka keluarlah sebuah karya ASUS ZenFone yang menawan. Tidak main-main ASUS ZenFone mengeluarkan tiga produk andalan yang siap bersaing dinomor satu untuk pasaran gadget cerdas android di Indonesia.Ketiga produk ASUS ZenFone smartphone android terbaik sepertinya diperuntukkan untuk anda agar dapat memilih sesuai kebutuhan dan kegunaan sebuah teknologi komunikasi.Untuk warna pun bisa memilih, ZenFone memiliki beberapa warna-warna yang cantik, warna-warna yang biasa menjadi warna favorit dengan desain yang elegan dan mudah dibawa kemana saja.Selain itu, ukuran layarnya sangat elegan sehingga untuk melihat foto, vodeo, game, dan sebagainya memberikan hasil yang maksimal dengan layar penuh.

Hasil penelitian menunjukkan bahwa variabel desain berpengaruh signifikan terhadap kepuasan konsumen.Menurut Kotler dan Keller (2009:10) bahwa desain produk yang baik juga berhubungan erat dengan tingkat kepuasan konsumen.Masalah desain dari suatu produk telah menjadi salah satu faktor yang perlu mendapatkan perhatian serius dari manajemen khususnya team pengembangan produk baru, karena sasaran konsumen yang dituju tidak sedikit yang mulai mempersoalkan masalah desain suatu produk yang mampu memenuhi kebutuhan dan keinginan konsumen.

\section{KESIMPULAN DAN SARAN}

\section{Kesimpulan}

1. Variabel atribut produk yang terdiri dari kualitas produk, fitur dan desain secara serempak berpengaruh signifikan terhadap kepuasan konsumen menggunakan smartphone merek Asus di Kota Palu.

2. Variabel kualitas produk berpengaruh signifikan terhadap kepuasan konsumen menggunakan smartphone merek Asus di Kota Palu.

3. Variabel fitur berpengaruh signifikan terhadap kepuasan konsumen menggunakan smartphone merek Asus di Kota Palu.

4. Variabel desain berpengaruh signifikan terhadap kepuasan konsumen menggunakan smartphone merek Asus di Kota Palu.

\section{Saran}

1. Kualitas produk yang ada pada produk smartphone Merek Asus sudah sangat baik hal ini ditunjukan dari angka beta terbesar dimiliki variabel ini. Asus sebaiknya mempertahankan kualitas produk yang tinggi dengan harga yang murah, fitur-fitur yang sudah ada pada produk ini juga harus ditambah dengan fitur-fitur dan desain yang membuat produk ini semakin unggul dan memberikan kesan modern kepada para konsumennya.

2. Saran untuk peneliti selanjutnya yang akan mengembangkan penelitian ini, sebaiknya menggunakan variabel-variabel lain yang tidak digunakan dalam penelitian ini seperti harga, dan bauran pemasaran. Hal ini dilakukan agar dapat diketahui variabel lain yang turut mempengaruhi kepuasan konsumen smartphone merek Asus. 
Sari, P.

\section{REFERENSI}

Gobe, M. (2005). Emotional Branding : Paradigma Baru Untuk Menghubungkan Merek Dengan Pelanggan. Jakarta: Erlangga.

Irawan, H. (2002). Sepuluh Prinsip Kepuasan Pelanggan. Jakarta: PT. Alex Media Komputindo.

Kotler, P. (2008). Identifikasi Kepuasan Pelanggan, Jilid 2. Jakarta: Erlangga.

Kotler, P., \& Amstrong, G. (2008). Prinsip-Prinsip Pemasaran, Edisi Keduabelas Jilid 1. Jakarta: Erlangga.

Kotler, P., \& Keller, K. L. (2009). Manajemen Pemasaran, Edisi Ketigabelas Jilid 1. Jakarta: Erlangga.

Kurniawan, A. (2014). Metode Riset Untuk Ekonomi \& Bisnis. Bandung: CV. Alfabeta.

Rangkuti, F. (2004). The Power of Brand. Jakarta: PT. Gramedia Pustaka.

Saputra, S., Hidayat, K., \& Sunarti. (2017). Pengaruh Kualitas Produk Terhadap Keputusan Pembelian dan Dampaknya Terhadap Kepuasan Konsumen Pengguna Iphone (Survei Pada Mahasiswa Fakultas Ilmu Administrasi Universitas Brawijaya Malang). Jurnal Administrasi Bisnis (JAB), Vol. 50, No. 6, September 2017.

Sugiyono. (2014). Metode Penelitian Bisnis. Bandung: CV. Alfabeta.

Sunarto. (2003). Prinsip-Prinsip Pemasaran, Cetakan Pertama. Yogyakarta: AMUS.

Tjiptono, F. (2006). Pemasaran Jasa. Malang: Bayu Media.

Tjiptono, F. (2008). Strategi Pemasaran, Edisi Kedua Cetakan I. Yogyakarta: CV. Andi Offset.

Umar, H. (2008). Metode Penelitian Untuk Skripsi dan Tesis Bisnis, Edisi Kedua. Jakarta: PT. Raja Grafindo Persada.

Utama, \& Amelia. (2009). Pengaruh Atribut Produk Terhadap Kepuasan Pelanggan Produk Teh Celup Sostro dan 2Tang (Survey Pada Pelanggan Teh Celup di Griya Pahlawan dan Giant Pasteur bandung). Jurnal Strategi, Volume 8, Nomor 16. 